\title{
T-Cell Surface Antigen CD2
}

National Cancer Institute

\section{Source}

National Cancer Institute. T-Cell Surface Antigen CD2. NCI Thesaurus. Code C15174.

T-cell surface antigen CD2 (351 aa, $\sim 39 \mathrm{kDa}$ ) is encoded by the human CD2 gene. This protein plays a role in both $\mathrm{T}$-cell activation and $\mathrm{T}$-cell adhesion to other cells. 